\title{
Stanislav Shvabrin (2019). Between Rhyme and Reason: Nabokov, Translation, and Dialogue. University of Toronto Press. 440 pp.
}

Nabokov is mainly known as a writer, but less so as a translator. Translation is indeed a somewhat neglected field in Nabokov studies, even if self-translation, his Russian rendition of Alice's Adventures in Wonderland or his literalist translation of Pushkin's masterpiece Evgenij Onegin into English (Eugene Onegin) are rites of passages for many Nabokov researchers. The monograph by Stanislav Shvabrin, Between Rhyme and Reason: Vladimir Nabokov, Translation and Dialogue, sets out to correct this gap and connects the dots between Nabokov's writing and translating by showing how his practice as a translator influenced his work as a writer. This influence is studied through the prism of Bakhtin's theory of dialogism. The other major strong point of this monograph is that its chronological organisation, divided into five chapters, clarifies the evolution of Nabokov's vision of translation.

The book starts with a solid introduction consisting of three sections. First, Shvabrin shows that many scholars, especially non-Nabokovian ones intent on criticising Nabokov's Onegin, fail to understand that his vision of translation is not monolithic: they tend to place all of Nabokov's essays on translation on an equal footing when, in actuality, his vision evolved tremendously over the years. Shvabrin also debunks the idea - one could almost say 'myth' that Nabokov's literalism can be explained through his elitist intellectualism or his desire to appropriate the works he was translating. As Shvabrin emphatically writes at the end of the first section, "nothing could be further from the truth than the impression that he sought to turn translation and conversation about its risks into an echo chamber where his authoritative voice would drown out those of others" (p. 8). In the second section, Shvabrin explains his choice to study Nabokov through the prism of Bakhtin, despite all the apparent contradictions of such a choice: indeed, how could one pair Bakhtin, who claimed that "no speaker, let alone writer, can pretend to be the sole proprietor of words received from others" (p. 9), and Nabokov, who was adamant that no writer ever influenced him? (He famously claimed in 1962: "I have never belonged to any club or group. No creed or school has had any influence on me whatsoever" ${ }^{\mathrm{i} \prime}$. Shvabrin goes on to show another contradiction: as Nabokov was a "champion of artistic singularity" (p. 9), Bakhtin supposedly cannot be relevant to study him; however, intertextuality permeates Nabokov's studies. Shvabrin calls 'intertextuality' an "umbrella term designating the relationship of one literary text to others" that "has already proven useful to understanding Nabokov - when wielded judiciously by a sophisticated practitioner" (p. 11). This section is crucial and it successfully disentangles Bakhtin's dialogizm and Kristeva's intertextuality. It is the densest part of the entire book as far as theory is concerned (it might be a bit difficult to read for those not familiar with Bakhtin), but this density is compensated by the fact that close reading functions as Shvabrin's modus operandi for the remainder of the book, as he explains in the last section of the introduction. The relevance of Bakhtin's theory of dialogue to Nabokov is particularly clear when it comes to poetry, which occupies a privileged position in the monograph: thus, Shvabrin sheds light on this other part of Nabokov's art that often stands in the shadow of his prose. In the last section of the introduction, Shvabrin exposes his methodology, organisation and objectives. He explains that his starting point was "archival research and editorial work" (p. 24) and shows once again the relevance of work on Nabokov's manuscripts and unpublished materialii. 
Each chapter is composed of multiple sections, in which Shvabrin studies each of the texts translated by Nabokov thoroughly and methodologically. Unfortunately, this approach is not reflected in the table of contents, which is limited to the five chapters. A more detailed table of contents would have shown the exceptionally wide scope of Nabokov's translation practice and guided the readers in each of the chapters, which are between 34 and 120 pages long. Each section provides intelligent analyses of both the original text and Nabokov's translation, and one can only applaud Shvabrin's knowledge of the many languages from which Nabokov translated (mainly French and German, in addition to the usual Russian and English), as well as his mastery of prosody and literary analysis. And yet the aim of the monograph is never lost: each section ends with a focus on the dialogic links between the translations and Nabokov's later original works. Knowing the traces that each translation has left on his novels, poems, subsequent translations, etc. is crucial to any Nabokov scholar specialising in his practice, not only as a translator, but also as a writer.

The first chapter focusses on Nabokov's juvenilia ("Before Sirin: A Foretaste of Translation (1910-1919)"). Once again, Shvabrin sheds light on a neglected part of Nabokov's art. This chapter studies a great variety of texts, mainly poetry, translated from numerous languages. It starts with Mayne Reid's Headless Horseman, which Nabokov famously translated into French alexandrines at the age of eleven; later on, Byron comes up to complete the repertoire in English. Nabokov also translated from French (Musset, Richepin or Régnier, and Belgian poet Emile Verhaeren), from German (six Lieder by Heinrich Heine) and once from Italian (none other than Petrarch). Among the many finds by Shvabrin is the revelation that interactions with Musset, Heine or Régnier through translation marked the entrance of the doppelgänger theme into Nabokovian art, or that the presence of potustronnost' in his translations of Petrarch's and Verhaeren's works shows that this theme predated the experience of loss that accompanied his departure from Russia (p. 47). Shvabrin also examines Nabokov's translation of three of Pierre Louÿs's Chansons de Bilitis, a literary hoax (or pseudotranslation) that left its mark in Glory or Ada, and shows, thanks to Nabokov's manuscripts, that Petrarch's Laura indeed was an inspiration for The Original of Laura, even if Dmitri Nabokov claimed the contrary (p. 37).

The second chapter covers 1919-1936 ("Before Nabokov: Sirin Translates") and is the longest of the book (120 pages). It covers various authors, from small pieces to longer works such as the well-known cases of Lewis Carroll's Alice's Adventures in Wonderland and Romain Rolland's Colas Breugnon. The latter is usually mentioned in relation to the fact that Nabokov's father dared Vladimir to try to translate it into Russian because of the difficult dialect. However, the result, Nikolka Persik, is hardly ever studied in depth, or rather, it had rarely been before. Shvabrin provides a great number of crucial insights. To name but a few, he defends the idea that "Nabokov's adaptation ... marked the beginning of his career as a professional writer" (p. 79) and he shows the Russianisation at work in Nabokov's rendering. This adaptation is all the more important when one contrasts it with Nabokov's literalism a few decades later. Shvabrin's monograph also demonstrates the importance of Bakhtin when it comes to this translation of Romain Rolland's novel. Indeed, Shvabrin studies the "Rabelaisian barbarity" of its language, which is interesting when one knows that Bakhtin wrote his dissertation on Rabelais before beginning his research on dialogizm. In contrast with Nikolka Persik, Nabokov's translation of Alice's Adventures in Wonderland is very often studied; as Shvabrin states, "It is unfortunate that, to so many observers and interpreters Ania has remained the sole representative of 'Nabokov's beginnings'" (p. 109). It is all the more 
problematic because Ania is often presented as predating Nikolka Persik. In reality, this is technically incorrect, but unfortunately this fact is repeated from time to time by some scholars in their otherwise serious research on Nabokov's work. In addition to those two novels, Chapter 2 studies the many translations that Nabokov produced, be they from English (Rupert Brooke iii, Walter Savage Landor, Alfred Tennyson, Charles Lamb, ...), French, or German (Goethe). What is striking here is the number of classics that Nabokov translated: Keats's "La Belle Dame Sans Merci", Baudelaire's "Albatros", Verlaine's "Chanson d'Automne" or Rimbaud's "Le Bateau Ivre". A great number of these translations come with particularly brilliant analyses or discoveries; in particular, thematic connections, such as the link between Rupert Brooke and the otherworld (p. 99), the one between Lolita and Supervieille's Le Voleur d'enfants (p. 165) or the follow-up on the theme of the artist's place in the universe (from Nabokov's translation of Baudelaire's "Albatros" to The Defense, Invitation to a Beheading, Lolita or the short story "Leonardo"). The biographical insights are also noteworthy. For example, Shvabrin shows how Nabokov's fond recollection of 'Golden Syrup' in Speak, Memory probably originates from his translation of Seamus O'Sullivan, or how translation provided Nabokov with solace after his painful break-up with Svetlana Siewert. As for literary connections, one could also note the links that Shvabrin establishes between Nabokov's translation of Ronsard's "Quand vous serez bien vieille" and Yeats (p. 104), even though Yeats' taking inspiration from Ronsard remains a debated question (unfortunately, Nabokov's translations of Yeats have never been retrieved to this day). This chapter also mentions the first translations that Nabokov produced of Pushkin, be it into English or into French, or those he made of the English bard: Nabokov translated two of Shakespeare's sonnets and, even more fascinating, he prepared a Russian translation of Hamlet, which unfortunately never saw the light of day (p. 168), except for some excerpts which appear in Bend Sinister (Chapter 7). Finally, there are a few cases of close reading that are thrilling even for someone who is not a specialist of poetry. First, Shvabrin studies the two translations that Nabokov prepared for Musset's "Nuit de Décembre" $(1915,1928)$ and uses them to demonstrate Nabokov's evolution over 13 years. Then, as for Verlaine's poem "Chanson d'Automne", arguably the most well-known poem in French ever, especially its first three lines (Les sanglots longs / des violons / de l'automne), Shvabrin's close reading on Nabokov's rendition of its euphony is illuminating and perfectly carried out. Lastly, Shvabrin brilliantly studies the importance of Verlaine's "Art poétique" and, more importantly, how well Nabokov understood its crucial value for French prosody. The reason Nabokov translated the poem is that he utterly disliked Tkhorzhevskii's rendition of it and he wanted to "appease Verlaine's spirit" (p. 178).

Chapter 3, "Before Eugene Onegin: 'Sinning Lovingly, Sinning Tenderly' (1940-1955)", starts with Nabokov's arrival in the USA and ends before his translation of Onegin. It covers Nabokov's translations of many Russian authors, but also includes two crucial texts of Nabokov voicing his vision of translation. Thus, the chapter is in a way framed by "The Art of Translation" (1941) and "Pity the elderly translator" (1952). Shvabrin's analysis of Nabokov's 1941 essay (pp. 201-205) clearly explains that, at the time, Nabokov defended an artistic vision of translation (Shvabrin actually calls it "his preliteralist manifesto", thus helping to differentiate between the different phases of Nabokov's evolution). As for the poem "Pity the elderly translator", Shvabrin convincingly explains that it marks the end of this period of free translations and the beginning of Nabokov's literalism: "His dissatisfaction with the artistic mode of translation, however, reached a high point, prompting him to verbalise it in a poem composed on 17 March 1952" (p. 274). When it comes to the work of Russian authors that Nabokov translated (e.g., Batiushkov, Zhukovskii, Baratynskii, Khodasevitch, Akhmatova, Fet, 
Blok, Nekrasov), it is interesting to note that, with these translations, Nabokov had one clear intention: "to demonstrate to his students the extent of these Russian authors' integration into European culture" (p. 191), which is particularly interesting when one remembers that Nabokov started translating Onegin after his students prompted him to do so. All those poets are studied briefly, but in an extremely interesting way. The links with Nabokov's forthcoming creations are always to the point, and special mention should be made of the pages devoted to the squirrel in Pnin. The creature is beloved by Nabokovian critics, especially because of its links with Mira Belochkin. However, Shvabrin is, to the best of my knowledge, the first one to have traced its literary origin back to a poem by Nekrasov (pp. 261-263). While most translations from this period are studied on a couple of pages, Shvabrin devotes much more space to three poets who were central for Nabokov. The first section of this chapter focuses on Nabokov's translations of three pieces by Pushkin (Mozart and Salieri, The Covetous Knight and $A$ Feast during the Plague). To mention but the first little tragedy (a collaboration with Edmund Wilson), Shvabrin shows that Nabokov's previous translations of Shakespeare infused his translation of Pushkin, which is particularly relevant since the Russian bard appropriated "the Shakespearean dramatic idiom in his "little tragedies"” (p. 192), thus confirming the relevance of a chronological organisation for this monograph. The two other poets are Lermontov and Tyuchev, and the two volumes Three Russian Poets and its extended version Pushkin, Lermontov, Tyutchev are thoroughly studied in most of the fourth section (pp. 210266). Unfortunately, these discussions are harder to follow than the remainder of the book for anyone who is not a specialist of poetry and probably also because, for once, the dialogic links with Nabokov's original work are a bit scarce. However, these analyses lay the foundation for understanding Nabokov's translation theory for Onegin, which is discussed in the next chapter.

Chapter 4 focuses on the Eugene Onegin period (1955-1965), but investigates much more than this translation alone. The chapter starts with an illuminating section on the essay "Problems of Translation", and, more specifically, on its differences with the previous essay "The Art of Translation". Here, Shvabrin clearly states his corrective goal: "By underscoring the disparity between the two works, I aim to put an end to the long-standing practice of using the two essays as a continuous narrative, devoid of conflict and contradiction" (p. 277). Therefore, this section goes hand in hand with the pages devoted to "The Art of Translation" (Chapter 3) and confirms what has become apparent to the reader thanks to the chronological demonstration throughout the monograph: Nabokov's vision of translation evolved over the years and should not be reduced to a monolithic philosophy. The next section concentrates on the translation of Lermontov, which Vladimir and Dmitri Nabokov produced together, $A$ Hero of our Time (1958). It is a perfect link with theory since Shvabrin explains that this version was "a testing ground for the literalist doctrine of 1955" (p. 282). In Shvabrin's analysis of the translation, the reader has the pleasure to (re)discover some critics who are not often quoted in relation with Nabokov and his literalist theory: if Shvabrin does mention classic scholars such as Gershenkron, it is refreshing to read the interesting analyses that J. Thomas Shaw wrote about Nabokov's translations. The second half of the chapter focuses on Nabokov and Onegin and on what this translation reveals about Nabokov's relation to Pushkin. However, it is the section right before this, devoted to The Song of Igor's Campaign, which should draw special attention. Indeed, it sheds light on many overlooked elements of Nabokov's vision of translation. In the section, the reader learns a tremendous amount about yet another book which scholars know Nabokov translated, without knowing much about it (except the falling out with Jakobson, which Boyd documented so well). Not only does Shvabrin mention the 
major source of inspiration that The Song was for Pale Fire, but he also evokes the debate that raged about the authenticity of the original text (Slovo), which is reminiscent of a similar

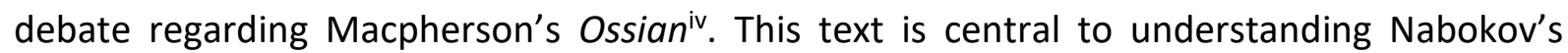
changing stance on translation: first, because Nabokov translated the Slovo on two occasions in two very different ways ("The Discourse of Igor's Campaign" (1952), then The Song of Igor's Campaign (1960)) and their comparison is illuminating; but it is also crucial because, contrary to what one would think, the second translation was not a literal one. Indeed, Nabokov produced a poetic translation (as the choice of 'song' for the title might suggest), thus choosing for once to favour rhyme over reason. Shvabrin's formulation sums up Nabokov's contradictions extremely well: "Sandwiched between such bulwarks of literalism as A Hero of our Time and Eugene Onegin, The Song of Igor's Campaign amounts to a major digression from the fundamental principles of the literalist doctrine" (p. 290).

The last chapter, "Beyond Eugene Onegin (1965-1977)", includes one section that deals with Nabokov's theory of translation (his essay "On Adaptation"), thus giving the last touch to a remarkably complete work on the matter at hand. However, the main feature of this chapter is, in my opinion, its surprising and refreshing contents. I will not spoil the reader's pleasure by divulging the contents of each section, but the list of topics can only whet the appetite of any Nabokov specialist or aficionado: Nabokov's translation contests, his Russian rendition of Abraham Lincoln's "Gettysburg Address", his occasional return to poetical, literary translation or his surprising decision to translate Okudzhava. It is very surprising when one knows how Nabokov objected to anything or anyone having to do, even remotely, with the USSR (e.g., Jakobson or Pasternak ignited Nabokov's ire because of their connections with the country). As Shvabrin writes, "Nabokov's ability to overcome his aversion to the political implications of Okudzhava's glorification of Bolshevism at its most violent is startling" (p. 326). What is also fascinating is how Shvabrin shows Nabokov's interest for music (Okudzhava was "a singersongwriter", "the modest hero of 'guitar poetry'" (p. 323)) and he does so on several occasions in the book, for example, in connection with Louÿs and Debussy, or with Heine, Schubert and Schumann. Thus, he shows how Nabokov's affirmation that he had no interest for music ${ }^{v}$ should be taken with a pinch of salt.

In conclusion, Shvabrin brilliantly completes his mission, which he sums up in his conclusion: "to make sense of the most contentious and least studied aspect of Nabokov's literary legacy, his lifelong involvement with translation" (p. 339). He paints a thorough and uncompromising image of Nabokov, the homo traductoris, as he called him in his introduction, and manages to untangle things, which is no small feat, since Nabokov's practice and theory of translation are closely intertwined. When one reads Shvabrin's monograph, it is clear that he is a great admirer of Nabokov in addition to being one of the most knowledgeable scholars on the smallest details of Nabokov's life and art, all while never shying away from showing Nabokov's contradictions, sometimes to redeem them, sometimes not.

\section{Julie Loison-Charles}

Univ. Lille, ULR 4074 - CECILLE - Centre d'Etudes en Civilisations Langues et Lettres Etrangères julie.charles@univ-lille.fr

\footnotetext{
' Vladimir Nabokov, Strong Opinions, New York: Vintage International, 1990 [1973], p. 3.

ii Anyone interested in archives can find fascinating material in the Berg collection (New York Public Library) or in the Library of Congress (Washington), which are the two mains locations for the Vladimir Nabokov Papers.
} 
However, some of these unpublished documents are now available in print in the collection that Brian Boyd and Anastasia Tolstoy edited and translated: Vladimir Nabokov, Think, Write, Speak: Uncollected Essays, Reviews, Interviews, and Letters to the Editor (New York: Knopf). Therefore, some documents mentioned by Shvabrin in his monograph (released at the end of May 2019) are now available in Think, Write, Speak (published in November 2019).

iii See, in Think, Write, Speak, the essay in Russian that Nabokov wrote on this poet in 1921 and which is translated into English and published for the first time.

iv There is actually a fascinating network of connections between The Ossian, Pale Fire and The Song, and Shvabrin's book is the occasion to (re)discover yet another noteworthy article: Priscilla Meyer, "Igor, Ossian, and Kinbote: Nabokov's Non-Fiction as Reference Library", Slavic Review 47, nº 1 (1988): 68-75.

${ }^{\vee}$ See Strong Opinions, p. 35 for example. 